\title{
ANALISIS KUALITATIF KANDUNGAN SAKARIDA DALAM TEPUNG DAN PATI UMBI GANYONG (Canna edulis Ker.)
}

\section{QUALITATIVE ANALYSIS OF CONTENT SACCHARIDE IN THE POWDER AND STARCH OF CANNA TUBERS (Canna edulis Ker.)}

\author{
Aprilia Kusbandari \\ Fakultas Farmasi Universitas Ahmad Dahlan Yogyakarta \\ JL. Prof. Dr. Soepomo, Janturan Yogyakarta Telp. (0274) 379418 \\ Email: kusbandari80@yahoo.com
}

\begin{abstract}
ABSTRAK
Umbi ganyong (Canna edulis Ker.) merupakan salah satu tanaman penghasil karbohidrat. Umbi ini juga mengandung protein, lemak, vitamin, mineral selain itu juga mengandung fosfor, besi dan kalsium yang tinggi. Penelitian ini bertujuan untuk mengidentifikasi kandungan gula yang terdapat dalam tepung dan pati umbi ganyong baik yang sudah mengalami hidrolisis maupun yang belum dihidrolisis. Metode yang digunakan untuk uji ini berupa uji tabung dan kromatografi lapis tipis (KLT). Dari hasil penelitian menunjukkan bahwa tepung ganyong yang belum dihidrolisis mengandung sukrosa $(\mathrm{Rf}=0,45)$ dan mannosa $(\mathrm{Rf}=0,51)$, setelah dihidrolisis menghasilkan glukosa $(\mathrm{Rf}=0,44)$, fruktosa $(\mathrm{Rf}=0,61)$ dan mannose $(\mathrm{Rf}=0,51)$, sedangkan pati ganyong mengandung glukosa $(\mathrm{Rf}=0,44)$ dan maltosa $(\mathrm{Rf}=0,35)$.
\end{abstract}

Kata kunci: Canna edulis Ker, sakarida, KLT

\section{ABSTRACT}

Canna Tubers (Canna edulis Ker.) is one of the plants producing carbohydrates. Its also contains of protein, fat, vitamins, minerals, phosphorus, iron and more calciums. The purpose of this study is to identify of sugar in the powder and starch from canna tuber is a hydrolysis and didn't hydrolysis. The method of qualitative analysis with tube test and Thin Layer Chromatography (TLC). The result indicated that before hydrolysis canna powder gave sucrose $(\mathrm{Rf}=0.45)$ and mannose $(\mathrm{Rf}=0.51)$, while after hydrolysis it gave glucose $(\mathrm{Rf}=0.44)$, fructose $(\mathrm{Rf}=0.61)$ and mannose $(\mathrm{Rf}=0.51)$. In addition, canna starch gave glucose $(\mathrm{Rf}=0.44)$ and maltose $(\mathrm{Rf}=0.35)$.

Keywords: Canna edulis Ker. saccharides, TLC.

\section{PENDAHULUAN}

Indonesia kaya akan plasma nutfah, salah satu diantaranya adalah umbi - umbian. Ganyong merupakan jenis umbi yang mengandung karbohidrat. Umbi Ganyong sangat baik untuk pertumbuhan anak balita karena karena mengandung fosfor, besi dan kalsium yang tinggi (Damayanti, 2007). Menurut Richana dan Sunarti, 2004, umbi ganyong memiliki kandungan karbohidrat $84,47 \%$. Selain kaya akan karbohidrat, umbi ganyong juga mengandung zat-zat lain seperti protein, lemak, vitamin dan mineral. Penelitian yang dilakukan oleh Thitipranphunkul et al (2003) menyebutkan kandungan gula pereduksi umbi ganyong hanya sekitar $0,77 \%$, pada penelitian tersebut tidak disebutkan mengenai varietas ganyong yang digunakan. Menurut Krisnayudha (2007) umbi ganyong memiliki jenis monosakarida berupa fruktosa dan oligosakarida yang dapat mendukung pertumbuhan bakteri asam laktat untuk menghasilkan prebiotik. Selain itu 
kandungan kimia berupa gula pereduksi melalui hidrolisis asam daapat menjadi bioetanol (Putri dan sukanda, 2008). Umbi ganyong juga mengandung flavonoid sehingga memiliki aktivitas anti ulserogenik dan perasan umbi ganyong terbukti sebagai anti ulser (Lestari, 2008).

Karbohidrat adalah komponen bahan pangan yang tersusun oleh 3 unsur utama, yaitu karbon $(\mathrm{C})$, hidrogen $(\mathrm{H})$ dan oksigen $(\mathrm{O})$. Susunan atom-atom tersebut dan ikatannya membedakan karbohidrat satu dengan yang lainnya, sehingga ada karbohidrat yang masuk kelompok struktur sederhana seperti monosakarida dan disakarida dan dengan struktur kompleks atau polisakarida seperti pati, glikogen, selulosa dan hemiselulosa. Analisis kualitatif karbohidrat umumnya didasarkan atas reaksireaksi warna yang dipengaruhi oleh produkproduk hasil penguraian gula dalam asam-asam kuat dengan berbagai senyawa organik, sifat mereduksi dari gugus karbonil dan sifat oksidasi dari gugusan hidroksil yang berdekatan. Reaksi dengan asam-asam kuat seperti asam sulfat, hidroklorat dan fosfat pada karbohidrat menghasilkan pembentukan produk terurai yang berwarna. Beberapa analisis kualitatif karbohidrat yang sering dilakukan adalah uji Molish, uji Seliwanof, uji Antrone, dan uji Fenol (Andarwulan et al., 2011).

Analisis kuantitatif karbohidrat dalam suatu bahan yaitu dengan cara kimiawi, cara fisik, cara enzimatik atau biokimiawi dan cara kromatografi. Penentuan karbohidrat yang termasuk polisakarida maupun oligosakarida memerlukan perlakuan pendahuluan yaitu dihidrolisa terlebih dahulu sehingga diperoleh monosakarida. Penentuan karbohidrat dengan cara kromatografi adalah dengan mengisolasi dan mengidentifikasi karbohidrat dalam suatu campuran. Isolasi karbohidrat ini berdasarkan prinsip pemisahan suatu campuran berdasarkan atas perbedaan distribusi rationya pada fase diam dan fase gerak (Sudarmaji, 2004 ). Untuk mengidentifikasi adanya polisakarida dapat digunakan kromatografi lapis tipis dengan cara menghidrolisis terlebih dahulu dengan asam. Hal ini dikarenakan polisakarida perlu diderivatisasi agar dapat terlihat pada lempeng kromatografi dan sulit larut dalam metanol. Karbohidrat terikat kuat pada fase diam sehingga fase gerak yang digunakan harus sangat polar. Fase gerak yang sering digunakan adalah butanol:piridin:air (Kaminska et al, 2009).

Penelitian ini bertujuan untuk mengidentifikasi adanya kandungan sakarida yang terkandung dalam tepung dan pati umbi ganyong (Canna edulis Ker.). Hasil penelitian ini diharapkan dapat memberikan informasi dan dapat dijadikan referensi untuk membuat bahan pangan dari umbi ganyong.

\section{METODE PENELITIAN}

\section{Bahan Penelitian}

Umbi ganyong yang digunakan berupa campuran ganyong merah dan putih diambil dari daerah Patuk, Gunung Kidul, Yogyakarta.

\section{Jalannya Penelitian}

\section{Pembuatan tepung umbi ganyong}

Proses pembuatan tepung umbi ganyong yaitu ganyong yang sudah terkumpul dikupas dan dicuci hingga bersih kemudian diiris tipis-tipis seperti membuat keripik. Irisan dilakukan secara melintang kemudian dipanaskan dengan oven pada suhu $60^{\circ} \mathrm{C}$ hingga mudah dipatahkan. Irisan ditepung dan diayak dengan ayakan ukuran 80/100 mesh. Kemudian dihitung rendemennya.

\section{Pembuatan pati}

Pembuatan pati ganyong dilakukan dengan mengupas kulit ari umbi ganyong, kemudian dicuci dan diparut. Hasil parutan kemudian diremas-remas dan dilarutkan dalam air kemudian disaring. Suspensi diambil kemudian dienapkan. Bagian padatan dicuci dengan air dan dienapkan (4-5 kali). Hasil endapan disebut pati. Pati basah kemudian dikeringkan dalam oven $60^{\circ} \mathrm{C}$ hingga kering dan diayak dengan ayakan berukuran 80/100 mesh, kemudian dihitung rendemennya.

Rendemen (\%) $=\frac{\text { berat endapan }(\mathrm{g})}{\text { berat simplisia basah }(\mathrm{g})} \times 100 \%$ 


\section{Pembuatan ekstrak}

Timbang masing-masing 5,0 gram sampel tepung simplisia dan pati ganyong kemudian dilarutkan dalam aquadest $100,0 \mathrm{ml}$ tambahkan $\mathrm{HCl}$ sampai $\mathrm{pH} 1$, kemudian direfluk dan disaring denga corong Buchner untuk mendapatkan ekstrak bebas endapan. Setelah itu disentrifuse untuk memaksimalkan pencampuran, ambil fase atas sebagai larutan uji.

\section{Analisis kandungan sakarida}

a. Uji Benedict

Sebanyak $1 \mathrm{ml}$ larutan sampel hasil ekstraksi dimasukan dalam tabung reaksi kemudian tambahkan reagen Benedict, gojog, kemudian didihkan dengan api kecil selanjutnya didinginkan. Hasil akhir yaitu terbentuk endapan warna merah bata jika sampel mengandung gula pereduksi.

b. Uji Barfoed

Sebanyak $1 \mathrm{ml}$ larutan sampel hasil ekstraksi dimasukan dalam tabung reaksi kemudian tambahkan reagen Barfoed campur dengan baik, kemudian didihkan dengan api kecil, perhatikan endapan merah yang terbentuk (Poedjiadi, 2009).

c. Uji Seliwanoff

Sebanyak $1 \mathrm{ml}$ larutan sampel hasil ekstraksi dimasukan dalam tabung reaksi kemudian tambahkan reagen Seliwanoff campur dengan baik, kemudian didihkan dengan api kecil, hasil positif ditandai dengan adanya larutan berwarna merah oranye.

d. KLT

Larutan ekstrak sampel dibuat konsentrasi $2 \mathrm{mg} / \mathrm{ml}$ kemudian sebagai pembanding digunakan standart glukosa, mannosa, maltosa, dan fruktosa, galaktosa. Kemudian filtrat dan standar ditotolkan $0,5 \mu \mathrm{L}$ pada lempeng KLT kemudian dielusi sampai batas tertentu.

\section{Analisis data}

Pada uji kualitatif untuk memastikan bahwa ekstrak yang diperoleh mengandung zat yang dianalisis. Data yang diperoleh kemudian dibandingkan dengan data yang ada pada teori. Sedangkan pada uji dengan KLT menunjukan senyawa gula apa saja yang ada dalam ekstrak sampel dengan menghitung harga $\mathrm{Rf}$ dan membandingkan dengan masing-masing standart dan sampel.

\section{HASIL DAN PEMBAHASAN}

\section{Pembuatan Tepung}

Proses pembuatan tepung umbi ganyong yaitu ganyong yang sudah terkumpul dikupas dan dicuci dengan alir mengalir. Pencucian ini bertujuan untuk membersihkan kotoran seperti tanah, cacing dan kotoran lain yang menempel. Umbi ganyong yang telah dicuci kemudian dikupas untuk menghilangkan kulit arinya, kemudian ditimbang dan diiris tipis-tipis untuk mempercepat dalam pengeringan. Irisan gayong dipanaskan dengan oven pada suhu $60^{\circ} \mathrm{C}$ ( 2 hari) hingga irisan ganyong mudah dipatahkan. Irisan diserbuk, lalu diayak tepung yang dihasilkan dengan ayakan ukuran 80/100 mesh. Kemudian dihitung rendemennya.

Rendemen dihitung dengan cara menimbang hasil serbuk yang sudah diayak $(\mathrm{g})$ dibagi dengan jumlah jumlah simplisia basah yang sudah dihilangkan kotoran dan kulit arinya dikalikan $100 \%$. Pada penelitian ini umbi ganyong yang digunakan untuk membuat tepung $5,0 \mathrm{~kg}$ menghasilkan tepung sebesar 875,50 gram sehingga rendemen yang diperoleh sebesar $17,51 \%$.

\section{Pembuatan Pati}

Pembuatan pati terdiri dari proses pengupasan, pencucian, pemarutan, peremasan, pengendapan dan pengeringan. Proses pengupasan dan pencucian bertujuan untuk membersihkan kulit dan kotoran yang menempel pada kulit luarnya, sedangkan proses pemarutan bertujuan untuk merusak jaringan umbi dan selsel umbi rusak dan agar pati dapat keluar. Dalam Hal ini dilakukan peremasan adalah untuk menyempurnakan kerusakaan jaringan dan dengan adanya tekanan dan penambahan air pada hasil parutan maka pati akan keluar. 


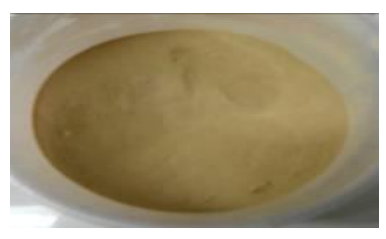

$\mathbf{a}$

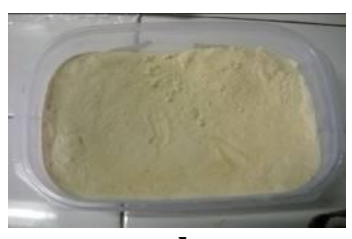

b

Gambar 1. a. tepung umbi ganyong ; b. pati umbi ganyong

Tabel I. Rendemen tepung dan pati umbi ganyong

\begin{tabular}{cccc}
\hline Sampel & Bobot umbi segar $\mathbf{( k g )}$ & Hasil $\mathbf{( g )}$ & Rendemen $(\%)$ \\
\hline Tepung & 5,0 & 875,50 & $17,51 \%$ \\
Pati & 5,0 & 270,80 & $5,41 \%$ \\
\hline
\end{tabular}

Rendemen dihitung dengan cara menimbang hasil pati kering yang diperoleh $(\mathrm{g})$ dibagi dengan jumlah jumlah simplisia basah yang sudah bersih dan dibuang kulit arinya dikalikan $100 \%$. Pada penelitian ini umbi ganyong yang digunakan untuk membuat pati sebanyak 5,0 kg menghasilkan pati sebesar 270,80 gram sehingga rendemen yang diperoleh sebesar $5,41 \%$. Tepung dan pati umbi ganyong dapat dilihat pada Gambar I, sedangkan rendemen Hasil rendemen tepung dan pati umbi ganyong dapat dilihat pada Tabel I.

\section{Hasil Ekstraksi}

Proses ekstraksi dilakukan untuk mengambil senyawa sakarida yang akan diteliti. Pelarut yang digunakan adalah air panas. Pemberian air panas ini bertujuan untuk melarutkan kandungan gula dalam sampel karena sifat gula yang polar larut dalam air.

\section{Uji Kualitatif}

Analisis kualitatif bertujuan untuk mengetahui dan membuktikan adanya senyawa senyawa tertentu dalam sampel. Penelitian ini menggunakan uji tabung berupa uji Benedict, uji barfoed dan uji seliwanoff. Uji Kualitatif lainnya yang digunakan untuk mengetahui jenis sakarida dalam sampel adalah Kromatografi Lapis Tipis.

a. Uji Benedict.

Uji Benedict bertujuan untuk mengetahui adanya gula pereduksi dalam larutan sampel.
Prinsip dari uji ini adalah gugus aldehid atau keton bebas pada gula reduksi yang terkandung dalam sampel mereduksi ion $\mathrm{Cu}^{2+}$ dari $\mathrm{CuSO}_{4} .5 \mathrm{H}_{2} \mathrm{O}$ dalam suasana alkalis menjadi $\mathrm{Cu}^{+}$ yang mengendap menjadi $\mathrm{Cu}_{2} \mathrm{O}$. Suasana alkalis diperoleh dari $\mathrm{Na}_{2} \mathrm{CO}_{3}$ dan $\mathrm{Na}$ sitrat yang terdapat pada reagen Benedict.

Pada uji ini menghasilkan endapan merah bata yang menandakan adanya gula pereduksi pada sampel. Endapan yang terbentuk dapat berwarna hijau, kuning atau merah bata tergantung pada konsentrasi gula reduksinya. semakin berwarna merah bata maka gula reduksinya semakin banyak. Pada Tabel II terlihat bahwa pati ganyong yang sudah dihidrolisis berwarna merah bata dibandingkan tepung, hal ini menandakan bahwa pati yang terhidrolisis mengandung gula reduksi yang lebih banyak. Hal ini terlihat pada Gambar 2.

\section{b. Uji Barfoed}

Pada uji Barfoed untuk mendeteksi karbohidrat yang tergolong monosakarida. Endapan berwarna merah orange menunjukkan adanya monosakarida dalam sampel. Ion $\mathrm{Cu}^{2+}$ dari pereaksi Barfoed dalam suasana asam akan direduksi lebih cepat oleh gula reduksi monosakarida dari pada disakarida dan menghasilkan $\mathrm{Cu}_{2} \mathrm{O}$ (kupro oksida) berwarna merah bata. Hal inilah yang mendasari uji Barfoed. Pada uji Barfoed, yang terdeteksi monosakarida membentuk endapan merah bata karena terbentuk hasil $\mathrm{Cu}_{2} \mathrm{O}$. Hal ini terlihat pada Gambar 3. 


\section{c. Uji Seliwanoff}

Pada uji Seliwanoff, jika gula tersebut mempunyai gugus keton disebut ketosa. Sebaliknya jika ia mengandung gugus aldehida, ia adalah aldosa. Prinsip dari uji ini adalah dehidrasi fruktosa oleh $\mathrm{HCl}$ pekat menghasilkan hidroksimetilfurfural dengan penambahan resorsinol akan mengalami kondensasi membentuk kompleks berwarna merah oranye.

Uji ini didasarkan pada fakta bahwa ketika dipanaskan, ketosa lebih cepat terdehidrasi daripada aldosa. Fruktosa dan sukrosa merupakan dua jenis gula yang memberikan uji positif. Sukrosa menghasilkan uji positif karena ia adalah disakarida yang terdiri dari fruktosa dan glukosa.

Hasil menunjukan positif mengandung gula pereduksi dengan adanya endapan merah pada larutan. dari hasil penelitian menunjukkan bahwa sampel tepung ganyong yang terhidrolisa memberikan warna oranye yang lebih pekat dibandingkan sampel yang lainnya. Hal ini terlihat pada Gambar 4.

\section{d. Kromatografi Lapis Tipis (KLT)}

Uji kromatografi lapis tipis bertujuan untuk melihat sakarida apa saja yang ada dalam sampel umbi ganyong. fase diam yang digunakan adala silika gel $G$ karena gula dapat berfluroresensi detrlah disemprot dengan pereaksi yang sesuai. sedangkan fase gerak yang digunakan etil asetat-isopropanol- air-piridin dengan perbandingan (26:14:7:2). Penampakan noda dengan menggunakan anilin difenilamin karena dapat mendestruksi noda sehingga membuat noda akan kelihatan yang dibantu dengan pemanasan.

Hasil percobaan diperoleh seperti pada gambar 5. Dari hasil perhitungan Rf diketahui bahwa sampel tepung ganyong yang belum terhidrolisa menunjukan harga Rf sama dengan mannosa $(0,51), \quad$ sukrosa $(0,45)$ setelah terhidrolisis akan menjadi glukosa $(0,45)$ dan fruktosa $(0,61)$ serta mannosa $(0,51)$.

Hasil elusi tidak menghasilkan Rf yang berbeda jauh karena struktur gula reduksi yang tidak jauh berbeda, sedangkan pada pati umbi ganyong mengandung amilum, amilum terdiri atas dua macam polisakarida yang kedua-duanya merupakan polimer dari glukosa. Amilum jika dihidrolisis menghasilkan glukosa dengan harga $\mathrm{Rf}=0,44$ dan maltosa dengan harga $\mathrm{Rf}=0,35$.

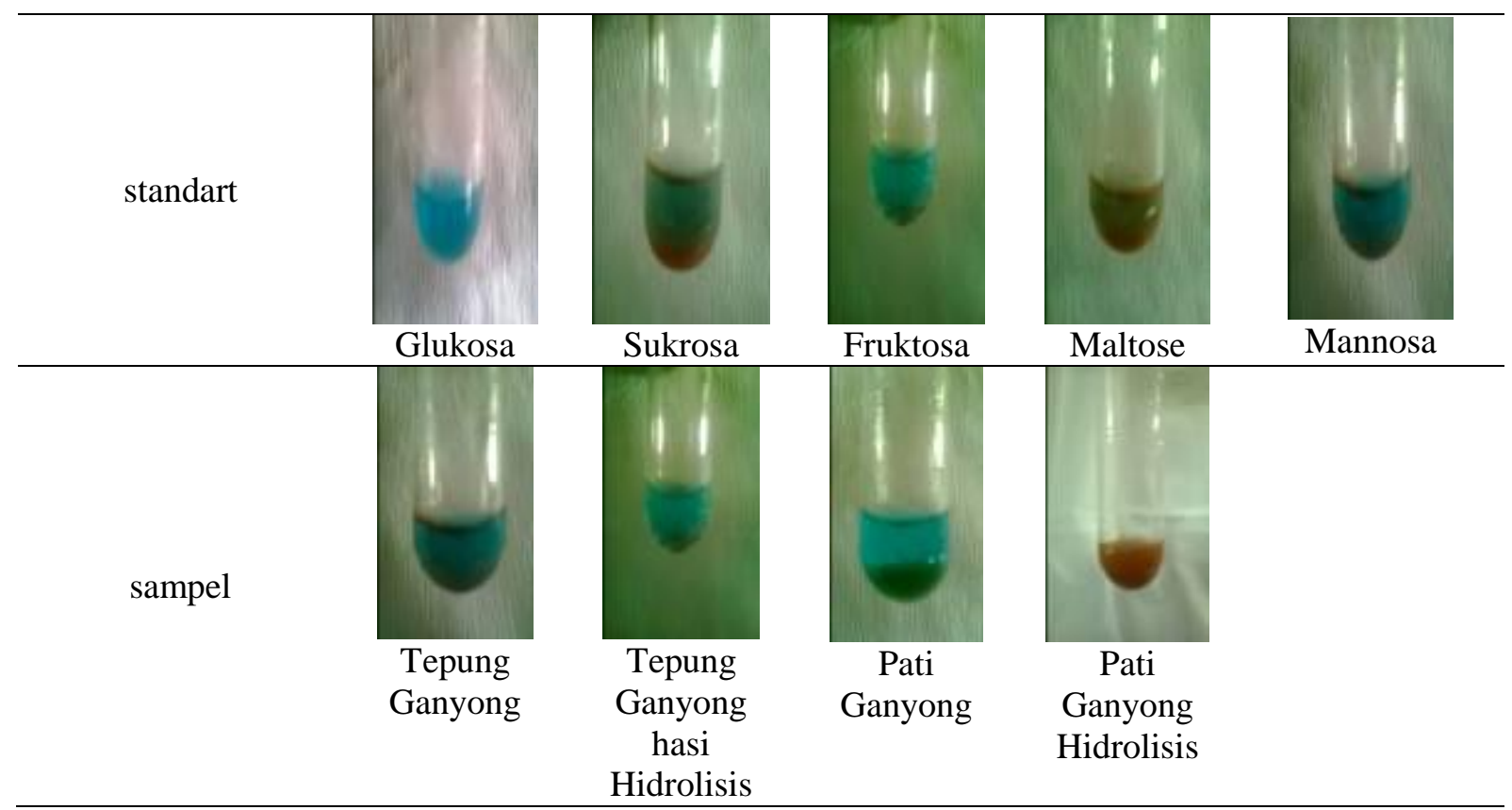

Gambar 2. Hasil uji benedict sampel tepung dan pati umbi ganyong dibandingkan dengan Standart 
Tabel II. Rendemen tepung dan pati umbi ganyong

\begin{tabular}{lcccc}
\hline No & Sampel & Bobot umbi segar $(\mathrm{kg})$ & Hasil $(\mathrm{g})$ & Rendemen $(\%)$ \\
\hline 1 & Tepung & 5,0 & 875,50 & $17,51 \%$ \\
2 & Pati & 5,0 & 270,80 & $5,41 \%$ \\
\hline
\end{tabular}

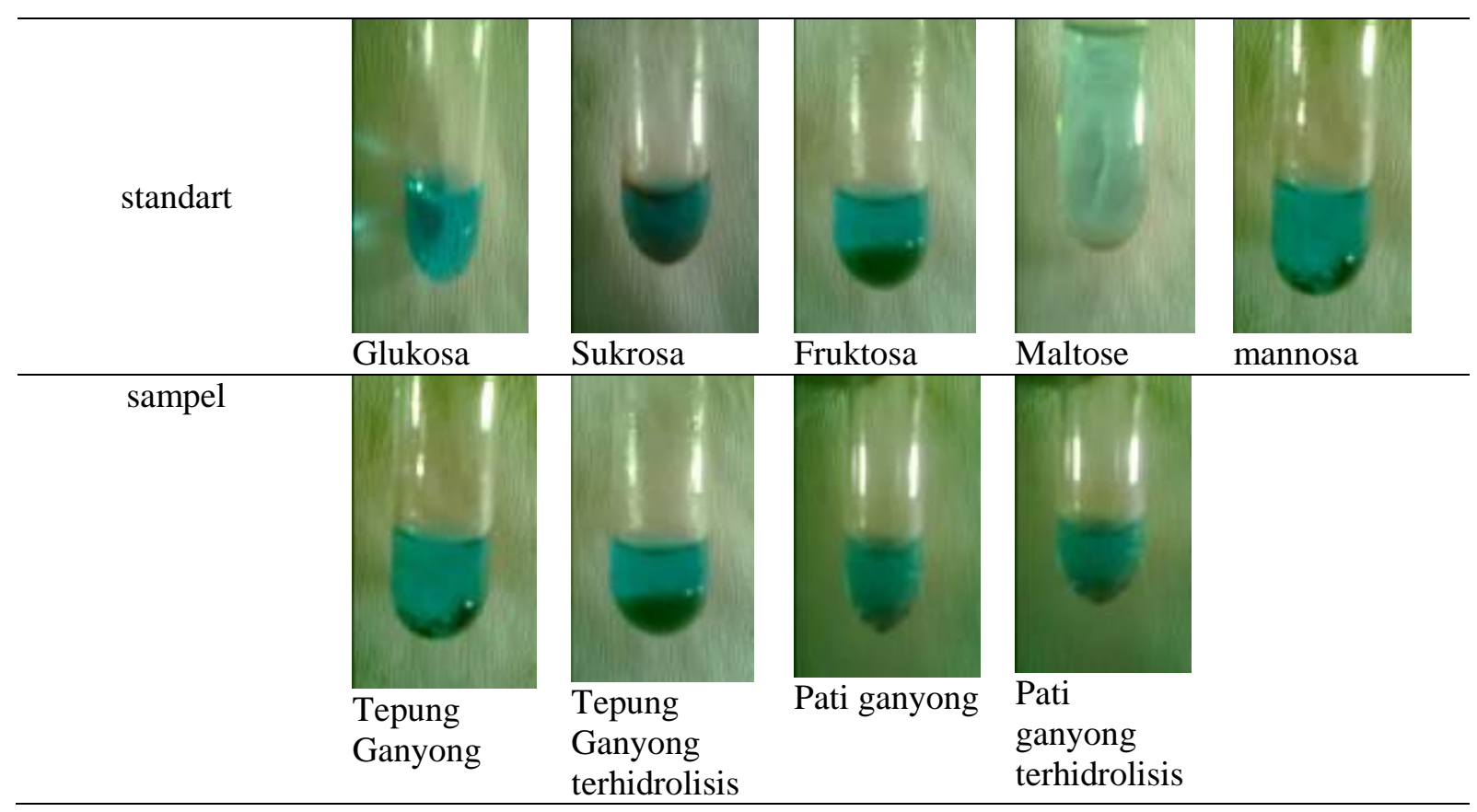

Gambar 3. Uji Barfoed sampel tepung dan pati umbi ganyong dibandingkan dengan standart

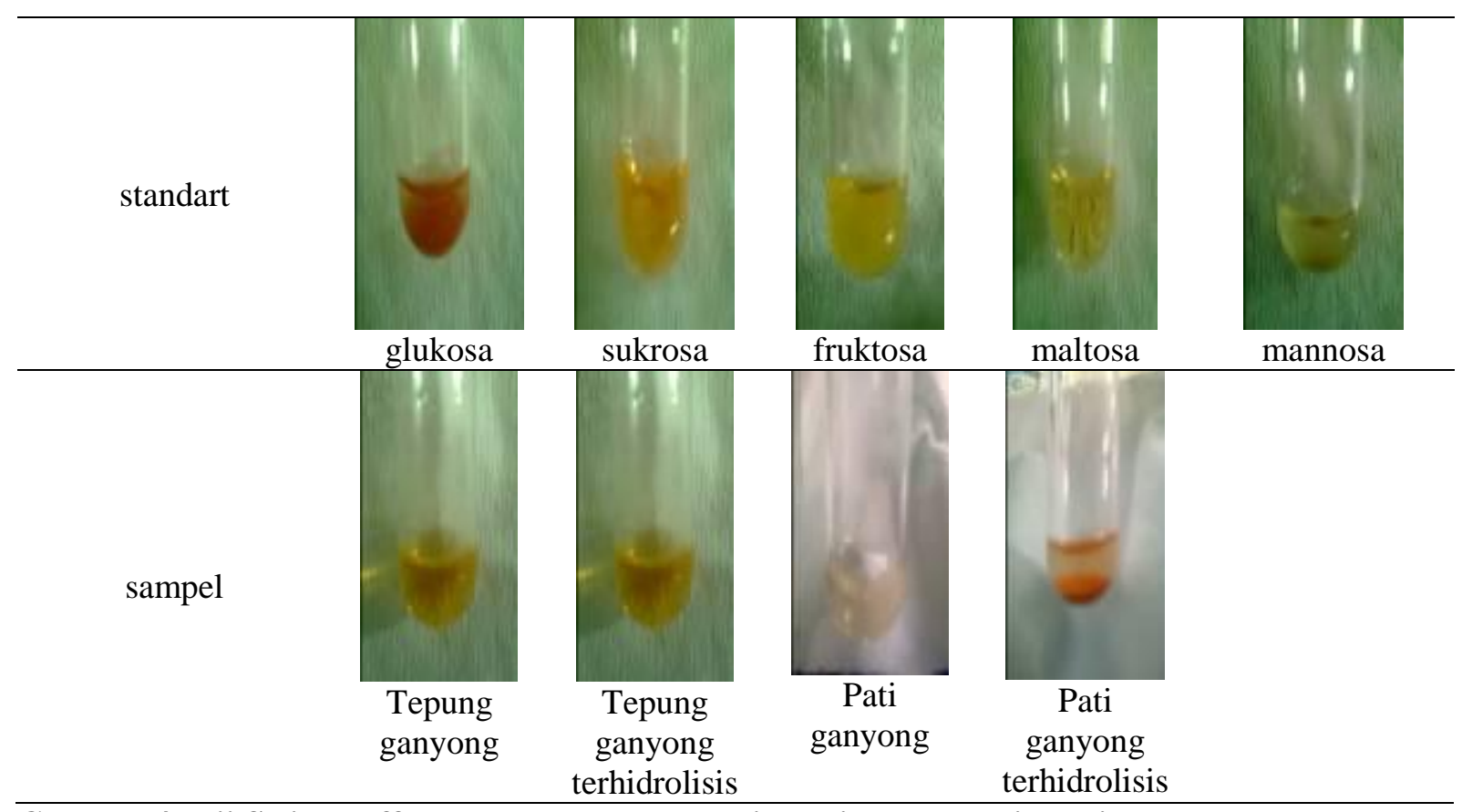

Gambar 4. Uji Seliwanoff sampel tepung dan pati umbi ganyong dibandingkan dengan standart 
Tabel III. Hasil kromatografi lapis tipis

\begin{tabular}{|c|c|c|c|c|}
\hline No & Jenis gula & & $\begin{array}{c}\text { Jarak elusi } \\
\text { bercak }\end{array}$ & $\mathbf{R f}$ \\
\hline 1. & Glukosa & & 3,5 & 0,44 \\
\hline 2. & Sukrosa & & 3,6 & 0,45 \\
\hline 3. & Galaktosa & & 3,3 & 0,41 \\
\hline 4. & Fruktosa & & 4,9 & 0,61 \\
\hline 5. & Maltosa & & 2,8 & 0,35 \\
\hline 6. & Mannosa & & 4,1 & 0,51 \\
\hline \multirow[t]{2}{*}{7.} & Sampel tepung ganyong yang tidak & a & 4,1 & 0,51 \\
\hline & terhidrolisa & b & 3,6 & 0,45 \\
\hline \multirow[t]{2}{*}{8.} & Sampel pati ganyong yang tidak & a & 3,5 & 0,44 \\
\hline & terhidrolisa & b & 2,8 & 0,35 \\
\hline 9. & Sampel tepung ganyong yang terhidrolisa & $\mathrm{a} ; \mathrm{b} ; \mathrm{c}$ & 4,$9 ; 4,1 ; 3,5$ & 0,$61 ; 0,51 ; 0,44$ \\
\hline \multirow[t]{2}{*}{10} & Sampel pati ganyong yang terhidrolisa & $\mathrm{a}$ & 3,5 & 0,44 \\
\hline & & b & 2,8 & 0,35 \\
\hline
\end{tabular}

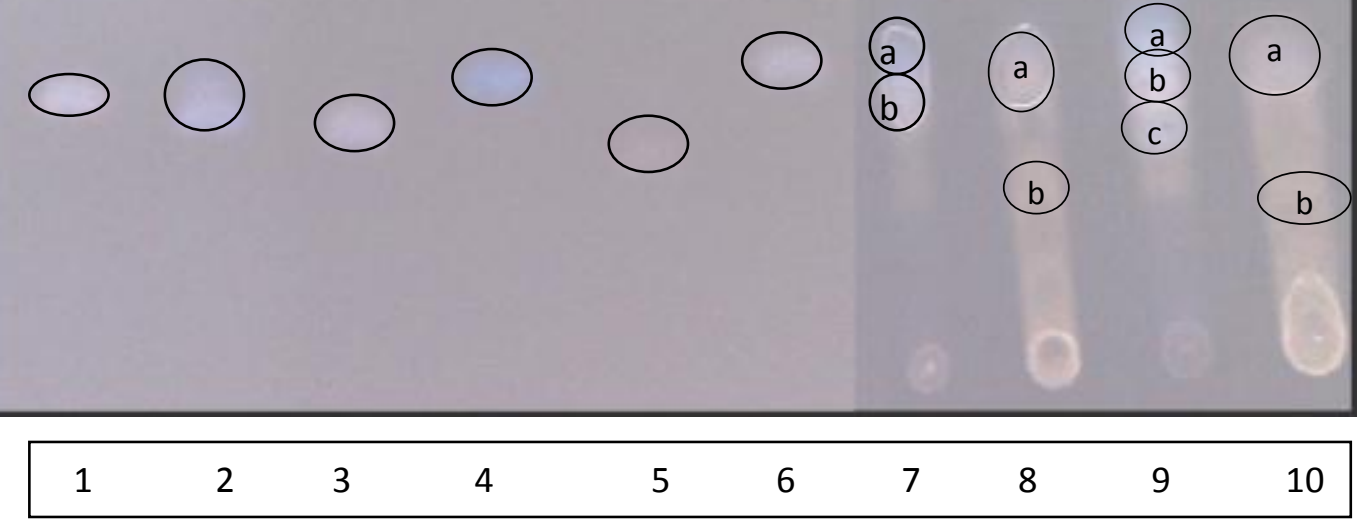

Gambar 5. Profil KLT standar sakarida dan sampel

Keterangan gambar :

Fase diam

Fase gerak

penampakan bercak

arah elusi

bercak 1

bercak 2

bercak 3

bercak 4

bercak 5

bercak 6

bercak 7

bercak 8

bercak 9

bercak 10

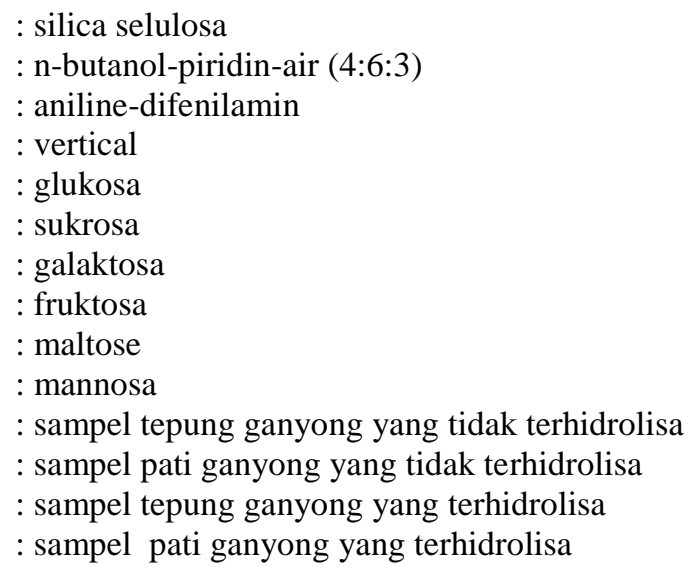

: n-butanol-piridin-air (4:6:3) 


\section{KESIMPULAN}

Berdasarkan hasil penelitian bahwa tepung ganyong sebelum dihidrolisis mengandung sukrosa dan mannosa, setelah dihidrolisis menghasilkan glukosa, fruktosa dan mannose, sedangkan pati ganyong mengandung glukosa dan maltosa.

\section{DAFTAR PUSTAKA}

Andarwulan, N., Kusnandar, F \& Herawati, D., 2011, Analisis Pangan, Dian Rakyat, Jakarta.

Damayanti, N.,2007, Pemanfaatan Umbi ganyong (Canna Edulis Ker) untuk membuat sereal bayi, Fakultas Teknologi Pangan UNISRI Solo.

Kamińska, A.S., Matysik, G., Kosior, M.W., Donica, H., \& Sowa, I. 2009, ThinLayer Chromatography of Sugars In Plant Material, Annales Universitatis MariaecurieSkłodowska, vol. XXII, N 4, 2.

Krisnayudha, K.,2007, Mempelajari Potensi Garut (Maranta arundiacea L) dan Ganyong (Canna Edulis Ker) untuk mendukung Pertumbuhan Bakteri asam Laktat, skripsi, Fakultas Teknologi Pertanian Institut Pertanian Bogor, Bogor.
Lestari, P., 2008, Uji efek Antiulcer Perasan Umbi Ganyong (Canna edulis Ker.) Pada Tikus putih Jantan galur Wistar, Skripsi, Fakultas farmasi Universitas Muhammadiyah Surakarta.

Putri, L.S.E dan D. Sukanda., 2008. Konversi Pati Ganyong (Canna Edulis Ker) menjadi bioetanol melalui hidrolisis asam dan fermentasi biodiversitas, 9(2) : 113-116.

Richana, N. \& Sunarti, T.C., 2004, Karakteristik Sifat Fisikokimia Serbuk Umbi dan Serbuk Pati dari Umbi Ganyong, Suweg, Ubikelapa dan Gembili, Jurnal Pascapanen 1(1): 29-37.

Sudarmadji, S., Haryono, B., \& Suhardi., 2004, Analisa Bahan Makanan dan Pertanian, Liberty Yogyakarta.

Thitipranphunkul, K.,Uttapap, D., Piyachomkwan, K takeda, Y.A.,2003 Comparative study of edible canna starch from different cultivars. Part I. Chemical composition and physicochemical properties. Carbohydrat Poly. 2003 (53): 317324. 